\title{
INVESTIGATING THE ENVIRONMENTAL PERFORMANCE OF THE WIND CATCHER IN JEDDAH
}

\author{
MADY MOHAMED* \& MOHAMMED F. M. MOHAMMED \\ Department of Architecture, Effat University, KSA
}

\begin{abstract}
With the emerging extensions to the City of Jeddah and the creation of the new urban agglomerations, arises a definite potential to enhancing environmental sustainability. This research explores the relationship between the traditional passive tools and their sustainable and transcendent qualities. People from ancient times used to employ traditional strategies and measures in their buildings. Both materials and technologies used since ancient times have allowed many vernacular architectures to last thousands of years. Some were made out of permanent materials such as stone while others were made out of more ephemeral materials such as adobe bricks or cob walls. However, vernacular measures such as Courtyard, Malqaf, Mashrabia, and Takhtaboush started to be abandoned in Jeddah. The main interest of the new trends in construction should progressively increase. However, these trends shall be undertaken by attempting to achieve the paradigm of sustainability in order to minimize the environmental impact of construction and its harmful effects on environment and human being such as the SBS (Sick Building Syndromes). Consequently, the overall durability of built structures and their eco responsiveness need to be assessed in order to enable new developers determine a more sustainable future plans. This paper is a part of an ongoing research project funded by KACST (King Abdul-Aziz City for Science and Technology) aims at investigating the potential of re-implementing the wind catcher in Jeddah's new residential buildings to address the climate-related aspects of Jeddah City to allow coping with the current and future needs and technologies. The current paper is aiming at investigating the environmental performance of the wind catcher and how such measures can enhance the IEQ (Internal Environment Quality). This is achieved through conducting a literature review on wind catcher and conducting a pilot study in AL-Balad (The old district in Jeddah).
\end{abstract}

Keywords: wind catcher, passive strategies and measures, heritage interventions.

\section{INTRODUCTION}

The achievement of adequate internal environment quality (IEQ) lies at the core of every debate about built environment of buildings. This is very important since poor environmental performance of buildings can negatively affect their occupants. McMullan and Seeley [1] identified this effect as temporary illness that could be called building related illness, tight building syndrome, office eye syndrome or more generally Sick Building Syndrome (SBS). The later term is recognized by the World Health Organization (WHO) [2]. The SBS is a misnomer, because buildings do not get sick, but rather building occupants can exhibit symptoms associated with being ill. The WHO identified a range of symptoms associated with SBS which cause genuine distress to some building occupants, but cannot be clinically diagnosed and therefore, cannot be medically treated. They typically include; stuffy nose; dry throat; chest tightness; lethargy; loss of concentration; blocked, runny or itchy nose; dry skin, and watering or itchy eyes; and headache [3].

Health and wellbeing of human being could be affected by buildings dramatically and particularly through the environmental physical factors. Human physical comfort is divided into; thermal, visual, and acoustic comfort. Visual comfort and acoustic comfort could be of

\footnotetext{
* ORCID: http://orcid.org/0000-0001-6831-176X

† ORCID: http://orcid.org/0000-0003-0119-5033
} 
great importance especially in certain buildings such as schools, auditorium, and universities. While thermal comfort is very important for all types of buildings. According to Givoni [4], there are several design details that affect the thermal performance of buildings in hot-dry zone which in turn affect the human thermal comfort. These are; i) Internal and attached open spaces, ii) Orientation of main spaces and windows, iii) Window size, location, and details, iv) The layout of the building's plan, v) Shading devices, vi) The colour of the building's envelope, vii) Building's materials, viii) Vegetation around and inside the buildings. Also, Ventilation devices, roof construction, and humidification strategies can be added to the above list [3]. Mohamed [5] classified the traditional passive techniques based on Fathy's classification and Givoni's affecting factors on thermal performance of buildings in order to devise an integrated classification system for the traditional passive ways of dealing with hot arid climate. The passive cooling devices that can enhance the state of thermal comfort inside buildings are [4], [6]-[8]:

- Sahn / Hosh:

- Malqaf:

- Nafora:

- Shesh:

- Takhtaboush:

- Mashrabiya:

- Rasha / Taka:

- Salsabil:

- Shuksheika:
The Courtyard

A wind catcher

The Fountain

The Venetian blinds

A covered outdoor sitting area at ground level open wooded lattice screens

A small opening at an upper level of a wall

A water-fed cooling plate

The vented or fenestrated lantern over the main hall

The location of Jeddah has a great impact on the prevailing climatic conditions in the city. Although Jeddah is located in the hot arid zone, its atmosphere is characterised with high temperature and humidity in most months of the year except for the winter, which moderate temperatures, and the year is divided into two seasons May and October, and the temperature separation begins from November to April. The climate is characterized by seasonal recreation and its times during the day. The moderate winter season of Jeddah is considered the most appropriate season for recreation. The moderate temperature helps attract tourists from the rest of the Kingdom and from abroad. While the practice of activities is limited for recreation in the summer on the evening when the temperature drops alone [9]. One of the basic elements of ancient Jeddah architecture is what applies to the ancestors of the successful architectural solutions taking into account the dampening of the atmosphere in the long summer months. In addition to overcome the harsh climatic reality by simple and authentic solutions that call for study and work on renewal so that they can be applied in modern architecture today and strive to developed. In a such climate of Jeddah, cross-ventilation is a necessity in buildings and for this reason perforated façades of decorative wooden screens and vertical ventilating shafts were used [10]. In the façade of the Hijazi House stands the wooden windows called "Al-Roshan", which are the prominent wood coverings of windows and exterior openings made of fine wood, Islamic inscriptions and quiet earth colors. [11].

The current research is focusing on one of the main features used among air movement strategies as a passive design measure which is the Malqaf (Wind catcher/Wind Tower). The wind catcher is known as an architectural tool that achieves indoor thermal comfort, a Persian element that has been used for decades. It is a tower with air outlets that rises above the building's façades to pull cold air down to enter the interior rooms of the house (Fig. 1). The external air movement of its dome creates a pressure differential that helps more air to the inside. It is often directed towards the prevailing wind to catch the air passing over the 
building, which is usually cooler and pushed into the building. It is a tower with wind ports above the building's façades to draw cold air down to enter the interior rooms of the house. The external air movement of its dome creates pressure differentials that help more air drag from the inside, so its presence with the Mashrabiya that opens up to the internal courtyard ensures the constant renewal of the cabin air. Some wind catchers were supplied with a soft or coarse wire mesh to clean the air of dust, impurities and insects, while others were supplied with burnt charcoal that helps absorb unpleasant odours from the air. The Malqaf is also useful in reducing the sand and dust in prevalent winds. The wind it captures above the building contains less solid material than the wind at lower heights, and much of the sand that does enter is dumped at the bottom of the Malqaf. It is also very useful in the dens cities, where the wind velocity at the level of the windows is very slow. It can also work as a wind escape; if its opening faced the opposite direction of the prevalent wind [12]. The size of the catcher depends on the temperature of the air outside. If the temperature at the entrance of the outlet is low, the area of its horizontal section should be large. If the temperature is higher than the maximum comfort of the thermal circumference, the area of its horizontal section should be small if the air is cooled inside by using a wet or wet charcoal sheet placed between two sheets of metal mesh. The air flowing over a water element such as the fountain can be directed to increase its moisture content [11].

In some designs, the drafts from the Malqaf outlet are cooled by passing over water. Moreover, by increasing the size of the Malqaf and suspending wetted matting in its interior, the airflow rate can be increased while providing effective cooling. It can be added to the Malqaf some panels of wet charcoal held between sheets of wire mesh (Fig. 2).

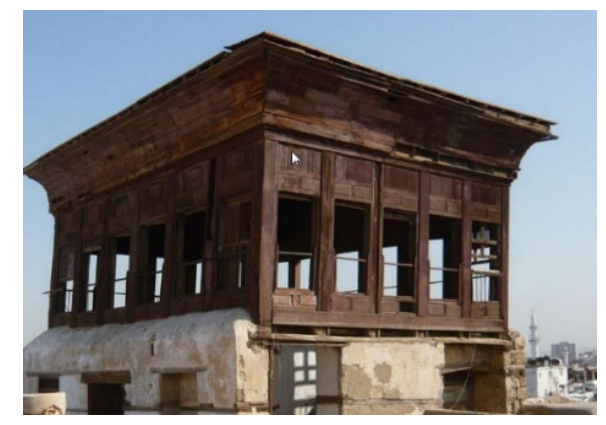

Figure 1: External view for Hijazi wind catcher style. (Source: Mady Mohamed.)

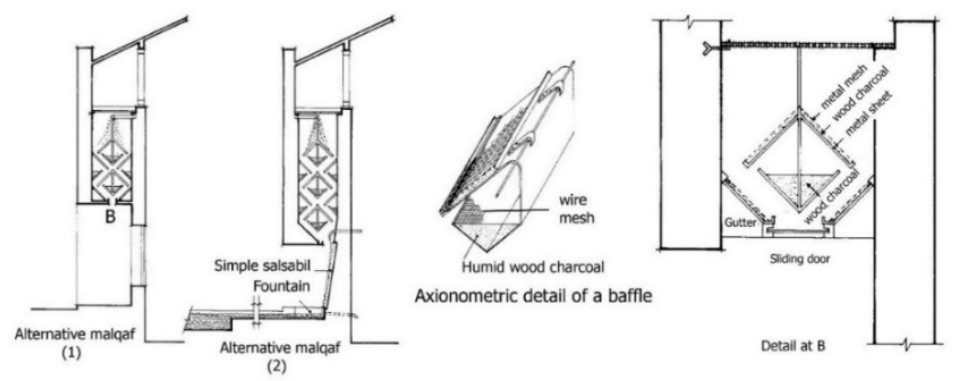

Figure 2: Details of alternative solutions for the Malqaf [6]. 
Evaporation can be further accelerated by employing the Bernoulli Effect or Venturi action with barricades of charcoal panels placed inside the Malqaf. The wind blowing down through the Malqaf will decrease the air pressure below the barricade, which increases airflow and thus accelerates evaporation. Metal trays holding wet charcoal can be advantageously used as barricades. Air can be directed over a Salsabil, a fountain or a basin of still water, to maintain the level of air humidity. The baffles are also effective in filtering dust and sand from the wind [6].

Contemporary designs of wind towers integrated advanced building techniques, for example [13]:

- Towers with evaporative cooling columns can increase the cooling potential of incoming air. This may require small pumps to feed the moisture into the system which can reduce the passive advantage of wind towers.

- Natural ventilation principles can dictate the exact height and cross section of the towers to accommodate for the target occupants in any building.

- Tower heads can accept wind from any direction without the airflow short circuiting.

- Control dampers and diffusers can modulate the volumetric flow rate.

- Solar collectors can be used as aids to promote stack effect ventilation in times or areas of little wind speed.

\section{RESEARCH AIMS}

This research aims at investigating the environmental performance of the Malqaf. This could be fulfilled through the following objectives: a) Studying the mechanism of the Malqaf, b) Analyze the previous work, and c) Conducting a pilot field study.

This will help to address the climate-related aspects of Jeddah City to allow coping with the current and future needs and technologies. Also, this will allow to overcome the disadvantages in order to utilize the Malqaf technique in Jeddah's new residential buildings.

\section{RESEARCH METHODOLOGY}

In order to achieve the goals of the research project, a designed research scientific methodology that has been published by the first author [3], [5], [13]-[16] and applied in real life projects will be used. This methodology was concerned by the process of quantifying the effectiveness of passive techniques. It includes three main studies; theoretical study, field study and computer-based study. The theoretical study is employed in order to identify the design targets and proposed successful strategies and measurements for achieving design goals. The field study is employed to measure and quantify the effectiveness of the current passive techniques. The computer-based study is utilized to quantify the effectiveness of the proposed passive techniques. The current paper employs the theoretical and the field study. A description of the nature of these studies is provided in the following.

a) Theoretical study: An intensive descriptive and analytical theoretical study is undergoing. The research team is employing its whole power with the involvement of the undergraduate and postgraduate students in addition to the research assistants. This aims also at raising the awareness between the staff and the students regarding this important topic.

b) Field study: Full-scale experimentation is probably the oldest method used to assess a physical phenomenon and supplies unarguable information. It is appropriate to collect information to assess directly the environmental performance or to compare a mathematical model with in-site measurements. The advantage of the experimental approach is that it deals with reality and therefore errors are limited to experimental 
procedures. Environmental equipment and data loggers for air temperature, humidity, ventilation, solar radiation and $\mathrm{CO}_{2}$ levels are being utilized in this part of the research. Among the famous houses in Jeddah that utilized the idea of the wind catcher are the historic Nasif House and Beit Noor Wali. These two examples will be utilized as a pilot for the field study.

\section{PREVIOUS WORK}

Many attempts have been made aiming to look into traditional ways of dealing with climate in the hot dry zone. Oliver [7], [8] presented and discussed the main features of traditional buildings in terms of structure, materials and styles. He also mentioned some passive ways that have been adopted by the Egyptians in their buildings such as; the Mashrabiya, Hosh, Dur-qa'a, and the courtyard. Fathy [6], discussed the principles and presented examples of natural energy and vernacular architecture in hot arid climate. He categorized the passive techniques in three main categories based on three main strategies; passive solar, natural ventilation, and evaporative cooling. Further demonstration for passive design strategies performance indicators were investigated within traditional architecture within hot arid zones by other researchers [17]. The environmental performance of Government primary schools in Egypt was investigated and found very poor [18]. In a different study, Mohamed [3] confirmed that using appropriate passive strategies and measures within the façade skin could enhance the thermal performance of the case studies by $13 \%$. Mohamed et al. [19] looked into the technical and social factors that led to the decline of earth Architecture in the Sahara Desert. The results suggested a strong possibility of reusing earth Architecture from the environmental point of view. However, a number of limitations were identified, including; durability, buildability and the attractiveness of the mud architecture to the locals. Filippi [20] analyzed the main characteristics of the urban pattern and buildings' typologies of the traditional earth architecture in two settlements of El-Dakhla oasis. Studies and applications have been developed to help in measuring the impacts of energy consumption while integrating passive and renewable energies, to further increase the energy consumption levels within educational buildings [21]. Iscandar [22] presented some neo-vernacular case studies of Michael Graves, Hassan Fathy and Ramses Wissa Wassef. Iscandar suggested that those examples show respect to the site, the natural environment, the climate and was successful in mixing traditional techniques with contemporary requirements.

Kamal [17] tried to evaluate various climate responsive passive design features that have been employed in the traditional architecture of Jeddah. He confirmed that the traditional architecture in the Hejaz region of Saudi Arabia evolved as a refined building art and technology. Jeddah was an important trading port, and thus cross-culturalization between the trading Middle-Eastern; Asian and European nations enriched the arts and architecture of Hejaz. The Hajj pilgrims who came from various parts of the world brought their skills and exchanged ideas with the local people. He continued to say that the traditional houses of Jeddah were built with three main considerations i.e. privacy, the segregation between men and women and response to the climate. The buildings are tall sometimes seven story high are airy structures which allow cross-ventilation. Generally, the houses extend 15-18 meters high, but the houses which are affected by the Ottoman architectural style, are of 3 to 4 story houses. The ground floor at street level is reserved for men and reception of guests and upper floor are reserved for women or family. Large houses have several rooms which may receive natural light and ventilation via a vertical shaft called Manwar. The buildings have larger openings and horse-shoe arches which are highly decorated as well as loggias opening to the sea. The projected bay windows (Roshans) are enclosed with decorative wood screens have screened windows - which provide cross-ventilation as well as privacy for family life. 
Table 1: Classification of wind driven ventilation techniques [23].

\begin{tabular}{|c|c|c|}
\hline $\begin{array}{l}\text { Wind driven ventilation } \\
\text { type }\end{array}$ & Feature/application & Typical flow rate \\
\hline \multicolumn{3}{|l|}{ Passive } \\
\hline Natural ventilation & $\begin{array}{l}\text { Wind pressure and stack effects Is } \\
\text { becoming more popular in modern } \\
\text { buildings. Primary method in most } \\
\text { domestic buildings, includes window } \\
\text { openings }\end{array}$ & $\begin{array}{l}\text { Can be the sole method of } \\
\text { ventilation }\end{array}$ \\
\hline Atria \& courtyards & $\begin{array}{l}\text { Architectural integration into building } \\
\text { Typically used in warmer climates for } \\
\text { cooling }\end{array}$ & No data available \\
\hline Wing walls & $\begin{array}{l}\text { Uses wind pressure mostly in domestic } \\
\text { buildings, used to facilitate natural } \\
\text { ventilation }\end{array}$ & $\begin{array}{l}\text { Up to } 40 \% \text { of outdoor wind speed } \\
\text { inside the room, only } 15 \% \text { without }\end{array}$ \\
\hline $\begin{array}{l}\text { Chimney/exhaust } \\
\text { cowls/roof vents }\end{array}$ & $\begin{array}{l}\text { Placed on top of chimneys and roofs, uses } \\
\text { wind induction and stack effect }\end{array}$ & $\begin{array}{l}\text { Various depending on size and } \\
\text { application. Can provide whole } \\
\text { building ventilation }\end{array}$ \\
\hline Wind Towers & $\begin{array}{l}\text { Wind pressure/stack effects Typically used } \\
\text { in warmer climates, now integrated as part } \\
\text { of natural ventilation strategy }\end{array}$ & $\begin{array}{l}\text { Depending on wind speed, direction } \\
\text { and height: up to } 73 \mathrm{ac} / \mathrm{h} / 300 \mathrm{l} / \mathrm{s} \text { for } \\
4 \mathrm{~m} \text { tower head }\end{array}$ \\
\hline Wind catcher & $\begin{array}{l}\text { Wind pressure/stack effects. Installed in } \\
\text { Schools, offices, domestic buildings, } \\
\text { industrial buildings }\end{array}$ & $\begin{array}{l}\text { Reported supply of } 100 \mathrm{l} / \mathrm{s} \text { and } 80 \\
1 / \mathrm{s} \text { extract at } 3 \mathrm{~m} / \mathrm{s} \text { wind speed }\end{array}$ \\
\hline Wind floors air inlets & $\begin{array}{l}\text { Wind floors are used on top of high-rise } \\
\text { buildings to facilitate natural ventilation. } \\
\text { Air inlets are components of natural } \\
\text { ventilation design }\end{array}$ & Various; little data available \\
\hline \multicolumn{3}{|l|}{ Directed passive } \\
\hline Cowls \& scoops & $\begin{array}{l}\text { Uses wind pressure and faces into or away } \\
\text { from prevailing wind (static) }\end{array}$ & $\begin{array}{l}150 \text { and } 2601 / \mathrm{s} \text { at } 6.5 \text { and } 9 \\
\text { ms/wind speeds. Chimney cowl on } \\
\text { a hybrid system provided up to } 55 \\
1 / \mathrm{s}\end{array}$ \\
\hline Rotating roof & $\begin{array}{l}\text { Dymaxion dwelling machine with a } \\
\text { rotating roof similar to a wind cowl. Used } \\
\text { to naturally ventilate whole dwelling }\end{array}$ & \\
\hline Wing jetter & $\begin{array}{l}\text { Uses drag and lift forces to create a } \\
\text { negative pressure and extract air }\end{array}$ & $\begin{array}{l}\text { Up to } 110 \mathrm{l} / \mathrm{s} \text { at } 6 \mathrm{~m} / \mathrm{s} \text { wind speed in } \\
\text { laboratory conditions. Lack of field } \\
\text { data }\end{array}$ \\
\hline \multicolumn{3}{|l|}{ Active } \\
\hline Turbine ventilators & $\begin{array}{l}\text { Combined wind turbine and extract fan } \\
\text { design. Domestic and industrial use }\end{array}$ & $\begin{array}{l}\text { Depending on size and wind speed } \\
\text { up to } 3001 / \mathrm{s} \text { per unit. } 20-501 / \mathrm{s} \text { for } \\
\text { domestic buildings for a small sized } \\
\text { ventilator. Rotating chimney cowls } \\
\text { provided } 35-901 / \mathrm{s} \text { dependent on } \\
\text { size and wind speed }\end{array}$ \\
\hline Rotating chimney cowl & $\begin{array}{l}\text { Small spherical rotating ventilator placed } \\
\text { on top of chimneys. Good at preventing } \\
\text { down draughts }\end{array}$ & $\begin{array}{l}\text { Between } 35 \text { and } 871 / \text { s depending on } \\
\text { size and wind speed }\end{array}$ \\
\hline Vawtex & $\begin{array}{l}\text { Vertical axis wind turbine attached to } \\
\text { extract fan }\end{array}$ & $\begin{array}{l}\text { No data available. Vawtex is being } \\
\text { installed in several buildings on a } \\
\text { pilot study }\end{array}$ \\
\hline
\end{tabular}

There are many examples, which exhibit the use of the wind catcher such as the AbdelRahman Nassif House (1974), in Jeddah, Saudi Arabia [10]. The design incorporates a revival of a complete climatic system including Malqaf, Qã'a (reception area), Dur-qa'a (central part of Qã'a), and wooden lantern [10]. 
Khan et al. introduced an extensive review for various wind driven ventilation designs regarding traditional means such like wind towers and more modern techniques including wind catchers and turbine ventilators. In this study, miscellaneous wind driven ventilation techniques have been reviewed and categorized. A summary of their features and typical flow rates is given in Table 1 [23].

Other examples of wind catcher and their techniques have been studied and examined. Bahadori et al. investigated an improved design of wind towers for natural ventilation and passive cooling. The study introduced an analytical base as a guideline for designing natural ventilation and passive cooling systems in the hot, arid areas of the world. The study proofed that the proposed design supplies air to the building at higher flow rates and with less dust [24]. Elmualim presented theoretical and experimental investigations and Computational Fluid Dynamics modelling considerations to examine the natural ventilation performance of a wind catcher system connected to the top of a test room. The experimental investigation using wind tunnel testing is vital in establishing the performances of wind catchers for natural ventilation in buildings particularly on large-scale models. Experimental results have much credibility in the research community as well in industry [25]. Al-Shaali et al. presented a technique to observe wind patterns and velocities inside and around different wind tunnel models in a very simple and inexpensive wind tunnel. The results of this experiment proved that the highest speed would be inside the wind catcher in the first third. Nevertheless, the wind decelerates in the middle zone then reaccelerates throughout the model until it reaches the exhaust [26]. The researches argued that the air movement pattern near the exit would not be affected by the size of the wind catcher; however, the speed slightly increased which open the door for more investigation regarding the relationship between the wind speed at the inlet and outlet of the wind catcher in relevance to the wind catcher and air column proportions.

\section{RESULTS AND DISCUSSION}

\subsection{Architectural description of Jeddah vernacular houses}

In terms of building geometry and settlement structures, courtyards and tight buildingpositioning are beneficial for cities in desert areas. In Jeddah, the south-facing façades receive the highest irradiation values, but can be efficiently shaded by cantilevers, overhangs and deep window soffits. The building should absorb just a link heal and a cool night breeze should chill the indoor rooms and keep the temperatures down until the next evening. To achieve this, a shaded building envelope with adjustable air permeability and a massive building core are necessary. A breeze blows constantly in Jeddah. At night, cool air comes from northeast, from the plateau of the Arabian Peninsula. During the day, humid air from the northwest gently touches the building surfaces, heated by intense direct solar radiation. This permanent air movement from a relatively constant wind direction provides a natural fresh air supply to the building, as well as cooler night ventilation.

The vertical section of the roof is equipped with an electric pull fan to increase the volume and the capacity of the air drive inside the outlet and to ensure that the air is flowing all the time - especially during the air silence and connected to tunnels and corridors of great lengths below the inner courtyard at the level of the basement floor $3 \mathrm{~m}$. These pipes are made of high density polyethylene or glazed pottery with diameters not exceeding 24 inches to ensure the quality of heat exchange between air and soil. Jeddah houses were multi-floor buildings (from 3 to 5), the upper floors receive the largest part of the wind and enter it inside the house through the light well to ventilate the house, white except for the wooden veneer, the openings were covered with two branches (to break the light of the sun and cover the sanctity 
of the house It is also used as interior panels resembling balconies) and wooden doors that reflect the Indian-Arab style of wood engraving. The houses of Jeddah were divided into three types according to its location for the warm and the exterior, a house with one façade such as the house of Noor Wali and a house with two façades like Nassif House, and other types of buildings as mosques, fields, warehouses, public buildings and markets [27]. By using the thermal inertia of massive coral stone walls, a heat sink can be built up and kept in the building core until the arrival of the next cool wind. Given the generally very high moisture content of the outside air the sorption capacity of coral stone and lime plaster does not improve the indoor climate significantly.

\subsection{Bait Nassif (Fig. 3)}

Beit Nassif, located in the heart of Jeddah, is known for its architectural design and its unique old design. It is also famous for having hosted King Abdul Aziz for a while previously, as well as being one of the architectural treasures that boasts the city of Jeddah. The Nassif House is close to restaurants, cafes and shops in the heart of the vibrant city, making it easy to reach by public transport. The Neem tree, known as the first tree in the city of Jeddah, stands in front of it, adding magic and a special glow to this house. This house expresses about a historical period from the era of the development of old architecture in Jeddah, which is the work of the great architect Hijazi teacher Suleiman Sursar. The residential rooms are situated in the north on the wind-facing side of the building. The side rooms such as the kitchen laundry room and toilet are situated at the exhaust air openings in the south. In between there are passages, a stairwell and a light-and-airshaft. The floor plan shows how the window openings break up the massively of the structure, reducing the volume of the north and west walls and the solid core around the stairwell and airshafts. Projecting screened windows (Rawasheen) or shish cover the large openings of the building envelope [28].

\subsection{Noor Wali House (Fig. 4)}

Noor Wali House is one of old houses in old Jeddah, It has a historical value that is one of the oldest historic houses of Jeddah at all, more than 150 years old and is one of the most beautiful historic houses in terms of shape and design and beautiful architectural appearance and Roashin and distinctive windows.

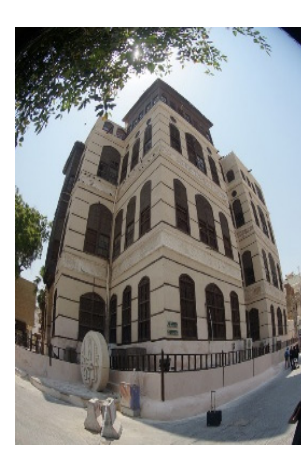

(a)

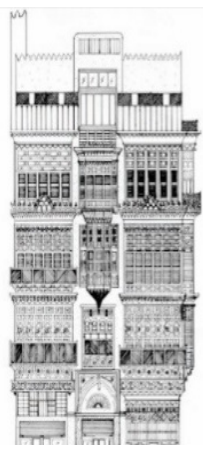

(b)
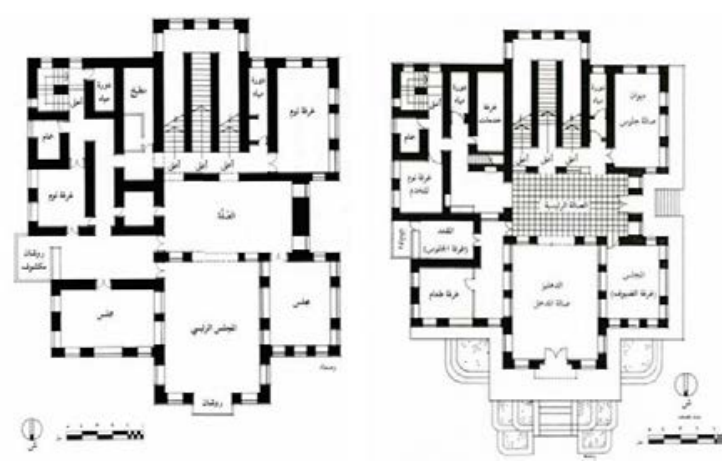

(c)

Figure 3: Bait Nassif. (a) External view; (b) The main elevation; (c) Ground and first plans. (Source: Mady Mohamed after [28].) 


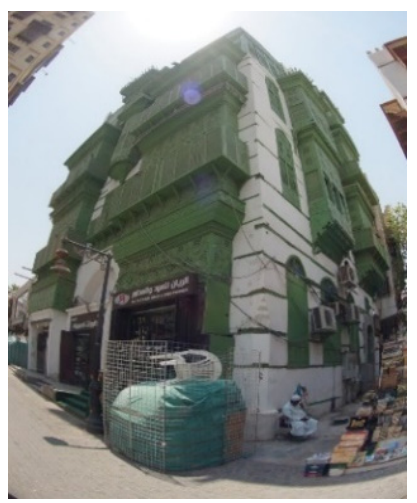

(a)

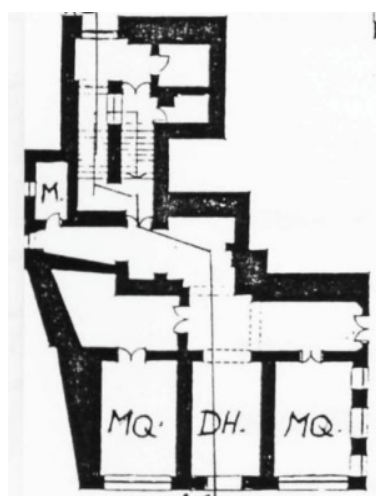

(b)

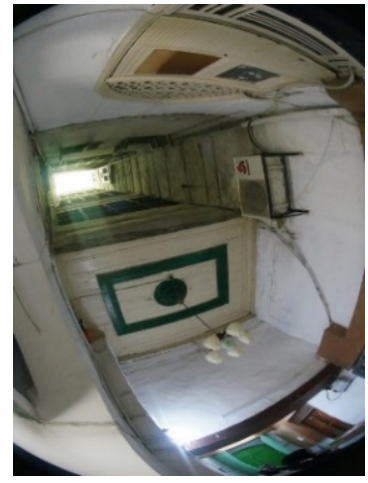

(c)

Figure 4: Bait Noor Wali. (a) External views; (b) Ground plan showing the location of the Malqaf; (c) Internal photo of the Malqaf. (Source: Mady Mohamed.)

\subsection{The pilot study}

A pilot study was conducted inside the two houses in May (one of the hottest months in Jeddah). It aimed at quantifying the effect of the Malqaf on the thermal performance of the building spaces. A group of the investigator and students visited the two house. The observation in addition to the objective assessment techniques have been employed in this investigation. The observation included using the mere eye and the professional camera with its different lenses. The objective assessment included using handheld equipment to measure the relative humidity, air movement. While a data logger equipment employed to monitor the air temperature and the $\mathrm{CO}_{2}$ level. $\mathrm{CO}_{2}$ level is considered the most important indicator for air quality. Fig. 5 shows the locations of the measurements inside the two houses. Regarding Bait Nassif, the objective assessment confirmed the hypnosis of the positive effect for the natural ventilation through the Malqaf. Two scenario were monitored, one scenario with the window facing the Malqaf closed and the second with the same window opened. Table 2 shows the results of the objective assessment. The results proved a good thermal performance for the space with the window opened. The results showed an air movement of $1.1 \mathrm{~m} / \mathrm{s}$ air movement for the first scenario while it was $0.0 \mathrm{~m} / \mathrm{s}$ for the second scenario. Moreover, a low average of $\mathrm{CO}_{2}$ equal to $395 \mathrm{ppm}$ while it was $560 \mathrm{ppm}$ with the window closed, an average level of relative humidity $59 \%$ while it was $65 \%$ with the window closed, and $32^{\circ} \mathrm{C}$ for air temperature while it was $33^{\circ} \mathrm{C}$ with the window closed.

As for Bait Noor Wali, we could monitor only one situation with the Malqaf opened. There was no ability to close the Malqaf. Table 3 shows the results of the objective assessment. The results proved a good thermal performance for the space. The records showed $0.7 \mathrm{~m} / \mathrm{s}$ air movement, a low average of $\mathrm{CO}_{2}$ around $428 \mathrm{ppm}$, an average level of relative humidity $60 \%$, and $32^{\circ} \mathrm{C}$ for air temperature.

The spec in the Rawasheen behind the wooden shutters was a constantly-ventilated place where the hot and humid air became bearable due to evaporation having a cooling effect on the skin. Moreover, on some summer nights, the occupants of the house slept on the roof terrace, the coolest part of the building, enjoying the starry sky and the light breeze. 


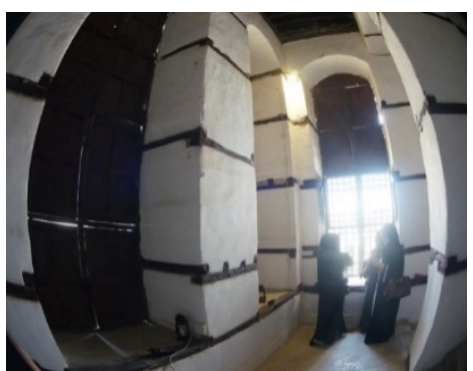

(a)

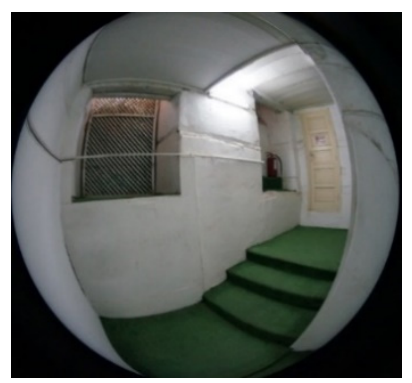

(b)

Figure 5: Measurement locations. (a) Location inside Bait Nassif; (b) Location inside Bait Noor Wali. (Source: Mady Mohamed.)

Table 2: The results of the pilot study in Bait Nassif. (Source: Mady Mohamed.)

\begin{tabular}{|c|c|c|c|c|}
\hline Time & $\begin{array}{c}\text { Wind } \\
\text { Speed }\end{array}$ & $\begin{array}{c}\mathbf{C O}_{2} \text { level } \\
\text { PPM }\end{array}$ & $\begin{array}{c}\text { Air temp. } \\
\mathbf{C}^{\circ}\end{array}$ & $\begin{array}{c}\text { RH } \\
\%\end{array}$ \\
\hline 10:30 am Closed Malqaf Window & 0.0 & 560 & 33 & $65 \%$ \\
\hline 11:00 am Opened Malqaf & 1.1 & 395 & 32 & $59 \%$ \\
\hline
\end{tabular}

Table 3: The results of the pilot study in Bait Noor Wali, (Source: Mady Mohamed.)

\begin{tabular}{|c|c|c|c|c|}
\hline Time & $\begin{array}{c}\text { Wind Speed } \\
\mathbf{m} / \mathbf{s}\end{array}$ & $\begin{array}{c}\mathbf{C O}_{2} \text { level } \\
\text { PPM }\end{array}$ & $\begin{array}{c}\text { Air temp. } \\
\mathbf{C}^{\circ}\end{array}$ & $\begin{array}{c}\text { RH } \\
\mathbf{\%}\end{array}$ \\
\hline $12: 00 \mathrm{pm}$ & 0,7 & 428 & 32 & $60 \%$ \\
\hline
\end{tabular}

\section{CONCLUSION AND RECOMMENDATIONS}

The climate at Jeddah forced many people traditionally, to use passive techniques to ventilate their buildings. In the past, and for successive periods, special procedures and have been proven to be successful despite their simplicity for climate treatment both at the small residential unit level of rural urbanization and city context. However, and because of the advanced technology such as the Air Conditioning System, people started to abandon these passive strategies and by turn, the knowledge of such useful strategies started to be lost.

The current research project and similar projects are raising the awareness again for these useful passive strategies that can reduce the required amount of energy to cool down our buildings. The research recommends the utilizing of the concept of the Malqaf in our contemporary housing.

\section{ACKNOWLEDGEMENTS}

This Paper contains part of the results and findings of a research project that is funded by King Abdul-Aziz City for Science and Technology (KACST), Grant No. (334-37- ص מa).

The second author would like to thank Effat University for its financial support for attending the conference. The authors also would like to thank the research team for their support and especially the Co.Is.: Dr. Aida Nayer and Dr. Sameer Felmban. 


\section{REFERENCES}

[1] McMullan, R. \& Seeley, I.H., Environmental Science in Building. 6th ed., Building and surveying series, Basingstoke, Palgrave Macmillan, 2007.

[2] WHO, Technical Meeting on Exposure-response Relationships of Noise on Health. World Health Organization Regional Office for Europe, European Centre for Environment and Health, Bonn Office, Bonn, Germany, 2003.

[3] Mohamed, M., Investigating the environmental performance of Government primary schools in Egypt: with particular concern to thermal comfort, in Dundee School of Architecture, Dundee University, Dundee, pp. 442, 2009.

[4] Givoni, B., Climate Consideration in Building and Urban Design. New York, USA: Van Nostrand Reinhold, 1998.

[5] Mohamed, M., Traditional ways of dealing with climate in Egypt, in The Seventh International Conference of Sustainable Architecture and Urban Development (SAUD 2010), S. Lehmann, H.A. Waer, and J. Al-Qawasmi, eds., The Center for the Study of Architecture in Arab Region (CSAAR Press): Amman, Jordan, pp. 247-266, 2010.

[6] Fathy, H., Natural Energy and Vernacular Architecture: Principles and Examples with Reference to Hot Arid Climates, University of Chicago Press, 1986.

[7] Oliver, P., Encyclopaedia of vernacular architecture of the world. Cultures and Habitats, Vol. 2, Cambridge, Cambridge University Press, 1997.

[8] Oliver, P., Dwellings, New York: Phaidon Press Limited, 2003.

[9] Mathew, R.E.A., Study of the Historical District of Jeddah, M.o.M.a.R. Affairs, Ed. Jeddah, Saudi Arabia, 1980.

[10] El-Shorbagy, A.-M., Design with nature: Windcatcher as a paradigm of natural ventilation device in buildings, International Journal of Civil \& Environmental Engineering IJCEE-IJENS, 10(3), 2010.

[11] Municipality, J., The Annual Report for Jeddah Historic Muncipility, Jeddah Muncipility Press: Jeddah, KSA, 2011.

[12] El-Wakeel, S.A.S.M., The Climate and the Hot Zones Architecture, Cairo: Alam Alkoteb, 1989.

[13] Mohamed, M. \& Gado, T., Application of computer based environmental assessment and optimization tools: An approach for appropriating buildings, in 3rd International conference ArchCairo, Appropriating Architecture taming Urbanism in the Decades of Transformation, Cairo, pp. 592-604, 2006.

[14] Mohamed, M. \& Gado, T., Investigating the process of exporting autodesk ecotect models to detailed thermal simulation software. Environment and Ecology Research, 2(5), 2014.

[15] Mohamed, M. \& Gado, T., Investigating the intelligence of the low-tech earth architecture of the Sahara: A feasibility study from the western desert of Egypt. Intelligent Buildings International (IBI), 2(2), pp. 179-197, 2010.

[16] Mohamed, M., An approach to integrate the environmental impact assessment process in the early stages of design, in The First International Engineering Conference Hosting Major International Events Innovation, Creativity and Impact Assessment, HBRC Housing \& Building National Research Center, Cairo, Egypt, 2013.

[17] Kamal, M.A., The morphology of traditional architecture of Jeddah: Climatic design and environmental sustainability. GBER, 9(1), pp. 4-26, 2014.

[18] Mohamed, M., Gado, T. \& Unwin, S., The environmental performance of classrooms in Egypt: a case study from El-Minya governorate, in The Second Scottish Conference for Postgraduate Researchers of the Built \& Natural Environment (PRoBE 2005), 
P.C.O. Egbu and M.K.L. Tong, Editors, Glasgow Caledonian University: Glasgow, pp. 643-651, 2005.

[19] Mohamed, M., Osman, M. \& Gado, T., Investigating the Revitalisation of the Intelligent Earth Architecture of the Sahara: A Case Study from the Western Desert of Egypt. IBI, In review.

[20] Filippi, F.D., Traditional architecture in the Dakhleh Oasis, Egypt: space, form and building systems, in PLEA2006 - The 23rd Conference on Passive and Low Energy Architecture, Geneva, Switzerland, 2006.

[21] Nayer, A., Assessment for a Typical Housing Prototype (THP), In terms of zero carbon effect, towards sustainable \& green built environment, in International Building Simulation Conference, Cairo, Egypt, 2013.

[22] Iscandar, M.F., Neo-Vernacular architecture in Egypt, in 3rd International Conference ArchCairo, Cairo, 2006.

[23] Khan, N., Su, Y. \& Riffat, S.B., A review on wind driven ventilation techniques. Energy and Buildings, 40(8), pp. 1586-1604, 2008.

[24] Bahadori, M.N., An improved design of wind towers for natural ventilation and passive cooling. Solar Energy, 35(2), pp. 119-129, 1985.

[25] Elmualim, A.A., Dynamic modelling of a wind catcher/tower turret for natural ventilation. Building Service Engineering, 27(3), pp. 165-182, 2006.

[26] Al-Shaali, R., Koenig, P. \& Schiler, M., Using a Helium Bubble Generator to visualize airflow patterns in and around building models, in The Annual Conference of the American Solar Energy Society, Austin, Texas, 2003.

[27] Al-Ghazzawi, A., The Heart of Jeddah, 2012.

[28] SCTA, Heritage Sites in Saudi Arabia, a special report about the heritage sites that registered and nominated to inscribe in the UNESCO WHC, SCTA.com, Riyadh. 2012. 